\title{
Intersections
}

Canadian Journal of Music

Revue canadienne de musique

\section{Jonathan Wisenthal, Sherrill Grace, Melinda Boyd, Brian Mcllroy and Vera Micznik, eds. A Vision of the Orient: Texts, Intertexts, and Contexts of Madame Butterfly. Toronto: University of Toronto Press, 2006. 262 pages. ISBN 0-8020- 8801-5 (hardcover)}

\section{Brad Bucknell}

Volume 27, numéro 1, 2006

URI : https://id.erudit.org/iderudit/1013169ar

DOI : https://doi.org/10.7202/1013169ar

Aller au sommaire du numéro

Éditeur(s)

Canadian University Music Society / Société de musique des universités canadiennes

ISSN

1911-0146 (imprimé)

1918-512X (numérique)

Découvrir la revue

Citer ce compte rendu

Bucknell, B. (2006). Compte rendu de [Jonathan Wisenthal, Sherrill Grace, Melinda Boyd, Brian Mcllroy and Vera Micznik, eds. A Vision of the Orient: Texts, Intertexts, and Contexts of Madame Butterfly. Toronto: University of Toronto Press, 2006. 262 pages. ISBN 0-8020- 8801-5 (hardcover)]. Intersections, 27(1), 128-131. https://doi.org/10.7202/1013169ar

All Rights Reserved (C Canadian University Music Society / Société de musique des universités canadiennes, 2007
Ce document est protégé par la loi sur le droit d'auteur. L'utilisation des services d'Érudit (y compris la reproduction) est assujettie à sa politique d'utilisation que vous pouvez consulter en ligne.

https://apropos.erudit.org/fr/usagers/politique-dutilisation/ 
létude. Pour sa part, Huq suggère qu'il ne peut y avoir interprétation sans une étude préalable, sans une implication sur le terrain où se vivent les expériences de la jeunesse et les musiques qui leur sont reliées. Par conséquent, toute subculture existe grâce aux rapports humains que des jeunes établissent entre eux, agrégeant croyances, systèmes de valeurs, pratiques, conduites et normes : une subculture évolue grâce à cette dynamique humaine. Si le chercheur ne fait que les observer, il ne peut les interpréter adéquatement. Cependant, lauteure ne propose pas une méthodologie définitive, mais laisse plutôt une porte ouverte à des interprétations multiples et à de nouvelles méthodes d'interprétation, ce qui peut donner l'impression à l'occasion que ses conclusions sont inabouties et que l'auteure erre plutôt que de prendre position. Cela n'enlève rien toutefois à la valeur scientifique de la perspective plus pragmatique que cherche à imposer Rupa Huq dans l'étude des youth culture. Il est difficile, par exemple, de parler d'un mets si lon n'y goûte point; de même, il est difficile de présenter une subculture si l'on n'y participe pas, bien qu'il soit évident que ce ne sera toujours que partiellement. Aller au-delà des subcultures devient en définitive le principe de base pour y pénétrer plus directement.

\section{RÉFÉRENCES}

Hall, Stuart, et Tony Jefferson, dir. 1976. Resistance through Rituals: Youth Subcultures in Post-war Britain. London: Hutchinson.

Hebdige, Dick. 1979. Subculture: The Meaning of Style. London : Routledge. Huq, Rupa. 2001. "Rap à la Française: Hip-hop as Youth Culture in Contemporary Postcolonial France ». Dans Transitions in Youth Citizenship in Europe: Culture, Subculture and Identity, sous la dir. d'Andy Furlong et Irina Guidikova, 41-60. Strasbourg: Council of Europe Publisher.

Rimmer, Dave. 1985. Like Punk Never Happened. London: Faber and Faber.

BRUNo DeschêNES

Jonathan Wisenthal, Sherrill Grace, Melinda Boyd, Brian Mcllroy and Vera Micznik, eds. A Vision of the Orient: Texts, Intertexts, and Contexts of Madame Butterfly. Toronto: University of Toronto Press, 2006. 262 pages. ISBN 0-80208801-5 (hardcover).

After reading this book and its very informative elaboration of the "Butterfly myth" (as the term suggests, a constant reference point is Puccini's Madama Butterfly [1904]), one will know a great deal more about Puccini's textual precursors: from the semi-autobiographical Madame Chrysanthème (1887) by Pierre Loti, the pen name of Julien Viaud, French sailor and novelist, to the short novel, Madame Butterfly (1898) by American John Luther Long, to David Belasco's play by the same name (1900), and finally to Puccini's opera. The volume also gives a strong sense that the Butterfly "ideal" is still floating about, as discussions of David Henry Hwang's M. Butterfly (1988), and David Cronenberg's film 
of that play (1993) show. The book has excellent scholarly apparatus, including a bibliography, an index (not always the case in collections of essays, and a very useful inclusion here), as well as end notes for each essay, and obviously marked in bold text (like hard-copy hot links) intratextual references to other essays within the volume. The book is based upon a seminar which was held in 1997, and, in some ways, the essays bear the burden of a certain familiar kind of new historicist/ cultural studies approach which depends a good deal on context to prove causality. The book might tell us little that is new in regard to colonial and postcolonial Western representations of the East; however, scholars will likely be selecting certain essays for their own needs, and they will on the whole be pleased with what they find. There is no way that I can touch upon all these essays in depth; therefore, my most detailed remarks will deal with the second section, since this part has perhaps the most interest for musicologists.

The book is divided into four sections, respectively, "Pre-Texts," "Texts," "Intertexts," and "Contexts," though many essays from one section could easily fit into another. The first section carries a single essay by editor Jonathan Wisenthal, and while there is a Preface to this book, Wisenthal's essay is the true introduction. Wisenthal's perceptive essay gives an overview of what is to come. He points out that in many of the precursor texts (eg. Belasco's play, Loti's story) the idea of the Orient is already "known" even before any of the characters arrive there. Readers and viewers, should they care to notice, are therefore warned that the perceptions of the characters are skewed. He wonders then if David Henry Hwang's $M$. Butterfly is really all that subversive of Puccini's opera, since, while Puccini's Pinkerton might essentialize the Orient in his view of Cio-Cio-San, the opera as a whole does not (10). Wisenthal suggests that in fact it is "the West [that is reduced] to a monolithic ideological identity" within the opera (10). If it's true that colonizers are changed as much as the colonized in the imperial experience, especially in the moment of identity creation, then Wisenthal's point is well made.

Susan McClary, whose essay begins the second section, would not agree. In asking why Puccini's opera remains so popular, even though its initial debut was not auspicious, McClary plays devil's advocate for the cause of justifying Cio-Cio-San's tragedy. She claims that Cio-Cio-San is the only character who "exhibits that most precious of Western properties: interiority" (23-24). Such accompanying traits as "nobility, loyalty, and heroism" (23) must, apparently, go along with this Western fantasy of subjectivity. (Are all claims to interiority dismissible as "Western"?) Western audiences and musicologists in particular have, in McClary's view, simply recovered Butterfly as a text that "empowers women and condemns imperialism" from the "advanced" position of "1990s ethical wisdom relating to class, race, and gender" (26). She suggests, via close examination of the score, that Puccini's music is "sadistic," that it is unlikely Puccini and his librettists were very interested in critiquing political power and gender politics in 1904 (26), and that the "immoral" Butterfly myth remains a pernicious influence socially, politically, and aesthetically in the post-WWII West.

Vera Micznik, also a musicologist, attempts the kind of recovery of which McClary is so critical. Micznik, who also examines the score, claims that Puccini's 
music expresses the abjection in Cio-Cio-San which exists even before the appearance of the fetishized other, Pinkerton. Micznik first explores the condition of the geisha and the "rashaman" or "women for rent" in Japanese culture and points out that it would have been rare for either an entertainer/ musician, such as a geisha, or a rented woman to have committed suicide. Geishas were in fact professional entertainers, and "rented" women, given in temporary "marriages" even to foreign travellers, were very much a part of ordinary (and oppressive) Japanese culture. However, using Kristeva's notion of abjection and McClintock's discussion of fetishization in colonial experience, Micznik goes on to suggest that Puccini's music articulates the divide that "must" have existed in these women between tradition and their "'private,' hidden, 'abject' psychological make-up" (45). She claims that Belasco's "naive and submissive" Butterfly (the one that interested Puccini most) is clearly a "Western concoction that satisfies the colonial impulse to assert superiority and domination of the West." However, while the opera is historically inaccurate, it nevertheless "acquires an authenticity credible both on a universal psychological basis and according to Western sensibility" (45). (A tricky statement, but one that can imply the possibility of a more intersubjective moment.) The abjection was there in Cio-CioSan even before Pinkerton arrived.

Melinda Boyd is critical not only of Puccini, but of Hwang's M. Butterfly, as well, even though the latter claims to deconstruct the opera. Boyd cannily links the falsely orientalized score to Hwang's play via problems of gender and racial authenticity as these are manifested in less central characters such as Suzuki (in Puccini) and the androgynous (though "straight") Comrade Chin in Hwang's play and in Cronenberg's film. Both film and play end up entangling characters in binaries of masculine-feminine, East-West, etc. Kate McInturff's elaborate essay attempts to link American operatic spaces of performance with Hwang's critique of the opera. Eventually, she reconstructs Hwang's Song as a kind of counter-diva for whom the "operatic character becomes the diva's tool" (85). This is a rich section, and its theoretical to and fro holds much that will be of interest to musicologists with a cultural bent.

Section Three begins with the longest essay in the volume, and in many ways one of the best. Bart Testa's sometimes heavily written piece follows the shifts in the Butterfly myth in its filmic manifestations throughout the century in order to give us a very subtle and well-informed reading of Cronenberg's revision of Hwang's play. To be very reductive, Testa seems to favour the film over the play, pointing out that Cronenberg's Gallimard, once having his orientalist "erotic pathology" (119) exposed, has no ability to return to any originary subject position: "desire and fantasy ... truly transform and there is no going back ..." (120). With rather nice pacing, this dense piece is followed with an almost informal examination of the 1957 Joshua Logan film, Syonara, starring Marlon Brando. Brian McIlroy's essay discusses how the tensions within both Japanese and American culture are negotiated in the film and its (at the time) radical approval of interracial relationships. This section concludes with a very fine essay by Sherrill Grace, comparing Hwang's play and Québécois playwright, Robert LePage's The Seven Streams of the River Ota (1996). Grace compares the use of 
Puccini by both playwrights, and concludes that Lepage's broader (and more complex) historical engagement is less vengeful and more hopeful than Hwang's play (but compare this to Testa's view of Hwang).

The final section on 'Contexts' begins with Richard Cavell's useful return to the question which actually lurks behind the whole volume: "Why Butterfly?" (158). His answer lies in an examination of Puccini's work and its offspring as indicative of "the concerns of cultures increasingly uncertain of their selfrepresentation within an increasingly mediatized and globalized technoscape" (158). Borrowing from the work of Anne McClintock and Rey Chow, among others, Cavell suggests that from Puccini on, there is no East or West for any character to call home since all are deracinated in the imperialist and postcolonial milieu. Maria Ng's essay compares Puccini's two oriental operas, Butterfly and Turandot (1924), and the differentiated historical relationships that the West had with both Japan and China (the setting for Turandot). However, "differentiations only serve to reinforce stereotypical identities and multiply the repertoire of biased rhetoric" (170). The operas are, of course, but reflections of particular Western views of these countries. Joshua Mostow's very interesting essay echoes Micznik's sense that Cio-Cio-San is a victim not only of Western imperialism, but of Japan's rewriting of its own history and of its re-appropriation of Western images of itself for its own imperial purposes. Mostow suggests that by the turn of the twentieth century, Japan's self invention was "serving as a model for nationalistic renewal in Europe and North America" (191). Like the essays by Testa, Micznik, Cavell, and Grace, this piece may be of special interest to a diverse audience looking for a more complex view of colonial and postcolonial relations. Similarly, Joy James's piece on Pierre Loti, arguably the inventor of the Butterfly myth, uses a very nuanced biographical reading of Loti to show how he deploys both a rather predictable set of orientalist race and gender images in his work, while at the same using this "colonial sexuality ... to resist dominant understandings of normative male sexuality" (197). The final essay by Rachel Ditor and Jan Selman examines the ways that subtle changes in the way scenes from Hwang's $M$. Butterfly are staged and acted can have significant effects on how the audience perceives and sympathizes with the characters. The piece suffers a bit since, of course, the variations are lost in the written text, and we only have the transcriptions of the way things were played and of audience reaction. Selman suggests that two male characters and a male author cannot adequately "question female constructs." Without mentioning any names, she concludes that " $[c]$ ritics with more insights than I tell me 'no", a man cannot be effective in this regard (236). Some binaries, it seems, must be maintained.

One hopes that in the decade since the initial seminar that many of these authors have gone on to expand the fine work begun here.

BRAD BUCKNELL 